Finanse, Rynki Finansowe, Ubezpieczenia nr 3/2017 (87), cz. 2

DOI: $10.18276 /$ frfu.2017.87/2-05

s. $53-65$

\title{
Podatkowa grupa kapitałowa na gruncie podatku od towarów i usług - ryzyko szacowania podstawy opodatkowania
}

\author{
Joanna Szlęzak-Matusewicz*
}

\begin{abstract}
Streszczenie: Cel - Podatkowa grupa kapitałowa jest formą łącznego opodatkowania grupy kapitałowej. Jej zastosowanie niesie wiele korzyści podatkowych, w tym m.in. możliwość stosowania cen transakcyjnych w transakcjach wewnętrznych podatkowej grupy kapitałowej. Na gruncie ustawy o VAT podatnikami są spółki tworzące podatkową grupę kapitałową a nie cała grupa jako całość. To z kolei oznacza, że ceny w transakcjach wewnętrznych powinny być rynkowe. Ujawnia się tu więc wewnętrzna niespójność przepisów. Przepis ustawy o VAT wyklucza zastosowanie przepisów ustawy o CIT. To z kolei rodzi ryzyko podatkowe. Celem rozważań prowadzonych w niniejszym artykule jest wskazanie źródła ryzyka podatkowego wynikającego z niespójności przepisów podatkowych i próba odpowiedzenia na pytanie, w jaki sposób ryzyko to można zminimalizować. Metodologia badania - W toku analizy autorka odwołuje się do przepisów podatkowych, interpretacji indywidulanych oraz orzecznictwa sądów administracyjnych.

Wynik - Autorka wskazała że ryzyko to można zminimalizować poprzez zastosowanie uprzednich porozumień cenowych lub zmianę ustawy o VAT, wprowadzając instrument vat grouping.

Oryginalność/wartość - Wartością artykułu jest przekrojowa analiza przepisów o podatkowej grupie kapitałowej - nie tylko w aspekcie podatku dochodowego, ale również z punktu widzenia opodatkowania podatkiem od towarów i usług.
\end{abstract}

Słowa kluczowe: podatkowa grupa kapitałowa, ryzyko podatkowe, uprzednie porozumienia cenowe, vat grouping, grupa vatowska, szacowanie, podstawa opodatkowania

\section{Wprowadzenie}

Na całym świecie wykształciły się dwie teorie opodatkowania grup kapitałowych - teoria rozdziału i teoria jedności gospodarczej. Wybór metody, uzależniony w wielu przypadkach od spełnienia określonych warunków, determinuje przyszłe obciążenia podatkowe. Istotą teorii rozdziału jest odrębne opodatkowanie wszystkich podmiotów wchodzących w skład grupy kapitałowej (Litwińczuk, 1995, s. 22). Niezależnie od tego, czy przedsiębiorstwo wykazuje związki kapitałowe, czy personalne z innym przedsiębiorstwem, na gruncie prawa

* dr Joanna Szlęzak-Matusewicz, Szkoła Główna Handlowa w Warszawie, Instytut Finansów, e-mail: joanna. szlezak@sgh.waw.pl 
podatkowego jest ono samodzielnym, pod względem prawnym i ekonomicznym, podmiotem prawa podatkowego. Za stosowaniem tej teorii przemawiają głównie względy prawne. Grupa kapitałowa, jako całość, nie ma osobowości prawnej, nie jest właścicielem majątku poszczególnych przedsiębiorstw i nie uzyskuje dochodu, zatem nie jest zasadne uznawanie jej za podmiot podatkowy. Konsekwencją oddzielnego opodatkowania jest przestrzeganie zasady arm's length, co oznacza, że powiązane ze sobą podmioty muszą we wzajemnych stosunkach gospodarczych traktować się tak jakby były niezależnymi od siebie podmiotaminie ma zatem możliwości stosowania we wzajemnych transakcjach cen odbiegających od cen rynkowych oraz brak możliwości interpersonalnego pokrywania strat jednej spółki grupy kapitałowej dochodem drugiej - tej samej grupy kapitałowej.

Teoria jedności gospodarczej z kolei jest podstawą traktowania grupy przedsiębiorstw jako jednego podmiotu podatkowego. Zgodnie z nią, grupa kapitałowa jako całość jest podmiotem podatkowym. Dzięki zastosowaniu tej teorii, wszystkie obroty między przedsiębiorstwami tej samej grupy kapitałowej mają neutralny charakter, przez co obciążenie podatkowe jest niższe w porównaniu z zastosowaniem teorii rozdziału. Dla przedsiębiorstw powiązanych wydaje się, że wybór tej metody jest rozwiązaniem słusznym i pożądanym, biorąc pod uwagę kryterium minimalizacji obciążeń podatkowych i wspólny cel gospodarczy. Opodatkowanie na zasadzie jedności wymaga jednak spełnienia od przedsiębiorstw wielu warunków. Najczęściej ustawodawstwa krajów Unii Europejskiej, nadając status podatkowy grupie kapitałowej, wymagają spełnienia następujących warunków:

- podmiot dominujący ma określony udział w kapitale zakładowym lub określoną liczbę głosów w organach stanowiących spółek zależnych,

- spółki zależne muszą być spółkami kapitałowymi,

- $\quad$ status podatnika może otrzymać tylko ta grupa kapitałowa, w której skład wchodzą przedsiębiorstwa mające siedzibę na terenie danego państwa.

Tak określone ogólne wymogi są modyfikowane przez państwa wprowadzające możliwość łącznego opodatkowania grupy kapitałowej. Wymogi te zazwyczaj dostosowane są do warunków wewnętrznych danego kraju. Na gruncie polskich przepisów odzwierciedleniem teorii jedności są przepisy ustawy o podatku dochodowym od osób prawnych o podatkowej grupie kapitałowej (dalej: PGK) ${ }^{1}$. Grupa spółek spełniwszy określone w tej ustawie warunki, może stać się jednym podatnikiem.

Korzystne dla grup kapitałowych regulacje istnieją jedynie na gruncie podatku dochodowego (dalej: ustawa o CIT). Podobnych regulacji brakuje na gruncie podatku od towarów i usług (dalej: ustawa o VAT). Brak systemowej spójności przepisów podatkowych rodzi ryzyko podatkowe związane ze stosowaniem cen transakcyjnych i ryzyko szacowania podstawy opodatkowania przez organ podatkowy.

1 Ustawodawcy podatkowi różnych krajów wprowadzają własne nazwy dla odróżnienia grup kapitałowych opodatkowanych łącznie od tych, które są opodatkowane na zasadach ogólnych, czyli oddzielnie. I tak np. w Niemczech, grupa kapitałowa otrzymująca status podatnika nosi nazwę Organschaft, w Danii - Sambeskatning, we Francji - Regime de l'integration fiscale. 
Celem rozważań prowadzonych w niniejszym artykule jest wskazanie źródła ryzyka podatkowego wynikającego z niespójności przepisów podatkowych i próba odpowiedzenia na pytanie w jaki sposób ryzyko to można zminimalizować. W toku analizy autorka odwołuje się do przepisów podatkowych, interpretacji indywidulanych oraz orzecznictwa sądów administracyjnych.

\section{Podatkowa grupa kapitałowa na gruncie podatku dochodowego}

Podstawowym założeniem podatkowej grupy kapitałowej jest możliwość łącznego opodatkowania spółek grupy kapitałowej. Oznacza to, że podatek jest obliczany od dochodu stanowiącego nadwyżkę sumy dochodów wszystkich spółek tworzących podatkową grupę kapitałową nad sumą ich strat (ustawa o CIT, art. 7a ust. 1). W praktyce więc strata jednej spółki jest pokrywana dochodem innej spółki tej samej PGK, w tym samym roku podatkowym, w którym została poniesiona (por. tab. 1). Nie ma zatem konieczności stosowania ograniczeń w odliczaniu straty jakie zobowiązane są stosować pozostałe przedsiębiorstwa opodatkowane na ogólnych zasadach (ustawa o CIT, art. 7 ust. 5). Z tego względu, podatkowa grupa kapitałowa jest postrzegana jako instrument optymalizujący wielkość płaconego podatku. Ten instrument warto polecić tym grupom, w skład których wchodzi chociaż jedna spółka ponosząca straty podatkowe.

\section{Tabela 1}

Rozliczenie podatku w podatkowej grupie kapitałowej

\begin{tabular}{llll}
\hline Spółki PGK & Dochód/Strata & $\begin{array}{l}\text { Podatek przed zawiązaniem } \\
\text { PGK (przy zastosowaniu } \\
\text { stawki 19\%) }\end{array}$ & $\begin{array}{l}\text { Podatek po zawiązaniu } \\
\text { PGK (przy zastosowaniu } \\
\text { stawki 19\%) }\end{array}$ \\
\hline A & 50000 & 9500 & \\
\hline B & -24000 & 0 & - \\
\hline C & 20000 & 3800 & 8740 \\
\hline Suma podatków ABC & & 13300 & \\
\hline PGK & 46000 & - &
\end{tabular}

Źródło: opracowanie własne.

Niewątpliwą korzyścią funkcjonowania w podatkowej grupie kapitałowej jest swoboda przepływów pieniężnych i innych aktywów między spółkami. Jest to szczególnie ważne, gdy spółki grupy są na różnych etapach rozwoju - gdy część z nich jest spółkami generującymi nadwyżki finansowe, a część tego finansowania potrzebuje. Wszelkie darowizny bowiem dokonywane w ramach podatkowej grupy kapitałowej są neutralne podatkowo - u obdarowanego stanowią przychód, który jednocześnie jest kosztem u darczyńcy (ustawa o CIT, art. 16 ust. 1 pkt 14). 
Neutralność podatkowa dotyczy również innych transakcji dokonywanych między spółkami podatkowej grupy kapitałowej. Spółki tworzące podatkową grupę kapitałową, zawierając wzajemne transakcje, nie podlegają bowiem regulacjom z zakresu cen transferowych, dzięki czemu mogą dodatkowo wpływać na wynik finansowy (ustawa o CIT, art. 11 ust. 8). Spółki PGK mogą więc swobodnie kształtować politykę cenową wzajemnych transakcji bez obawy, że organ podatkowy ją zakwestionuje, szacując odpowiednio dochód do opodatkowania.

Wśród korzyści funkcjonowania w podatkowej grupie kapitałowej wymienia się także realizację tzw. debt push down (Nowak, 2015, s. 5), czyli możliwość uznania kosztów finansowania nabywanej spółki za koszty podatkowe potrącane z dochodami nabytego podmiotu.

Zaletą funkcjonowania grupy kapitałowej jako całości na gruncie prawa podatkowego jest także uproszczenie rozliczeń podatkowych, ponieważ przed urzędem skarbowym całą grupę reprezentuje jedna spółka grupy, niekoniecznie spółka dominująca. Grupa kapitałowa ma swobodę w zakresie wyboru spółki reprezentującej.

Do 2007 roku niewątpliwą korzyścią opodatkowania grupy kapitałowej w formie PGK był brak opodatkowania dywidend (u spółki otrzymującej dywidendę) wypłacanych przez spółki zależne spółce dominującej. Od 2007 roku przy odpowiednim udziale spółki dominującej w spółkach zależnych (min. 10\%), ustawodawca wprowadził zwolnienie z opodatkowania dywidend, bez względu na to czy jest zawiązana podatkowa grupa kapitałowa, czy też nie (ustawa o CIT, art. 22 ust 4).

Regulacje podatkowe dotyczące możliwości tworzenia przez polskie spółki podatkowych grup kapitałowych zaczęły obowiązywać 1 stycznia 1996 roku. Sensu przyznania grupie kapitałowej statusu podatnika należy upatrywać w aspekcie (Wawrzyniak, 2002, s. 162):

- makroekonomicznym - rząd uznał potrzebę stworzenia instrumentu wspomagającego procesy restrukturyzacyjne w polskiej gospodarce,

- mikroekonomicznym - korzyści podatkowe dla przedsiębiorstw tworzących grupę.

W związku z tym, że na gruncie prawa podatkowego regulacje te były w owym czasie czymś zupełnie nowym i nie sposób było określić zainteresowania podmiotów tego typu strukturami, a w konsekwencji niemożliwe było również określenie skutków budżetowych wynikających z ich wprowadzenia, warunki utworzenia podatkowej grupy kapitałowej początkowo były bardzo restrykcyjne. Początkowo warunki te zostały sformułowane w taki sposób, że w praktyce znacznie ograniczały potencjalny krąg podmiotów mogących utworzyć taką grupę. W związku z brakiem zainteresowania podatników tworzeniem podatkowych grup kapitałowych (PGK), z roku na rok warunki te ulegały stopniowemu łagodzeniu (Kośmider, 2000, s. 7).

Warunki dotyczące podatkowych grup kapitałowych można podzielić na warunki utworzenia podatkowej grupy kapitałowej i warunki funkcjonowania spółek w formie skonsolidowanej. Zgodnie z obecnym brzmieniem przepisu, art. 1a ust. 2 pkt 1 ustawy o CIT, podatkową grupę kapitałową mogą tworzyć wyłącznie spółki z ograniczoną odpowiedzialnością lub spółki akcyjne z siedzibami na terytorium Rzeczypospolitej Polskiej, jeżeli: 
a) przeciętny kapitał zakładowy określony w sposób, o którym mowa w art. 1a ust. 2b, przypadający na każdą z tych spółek, jest nie niższy niż $1 \mathrm{mln}$ zł;

b) jedna ze spółek, zwana spółką dominującą, ma bezpośredni 95\% udział w kapitale zakładowym lub w tej części kapitału zakładowego pozostałych spółek, zwanych spółkami zależnymi, która na podstawie przepisów o komercjalizacji i prywatyzacji nie została nieodpłatnie lub na zasadach preferencyjnych nabyta przez pracowników, rolników lub rybaków albo która nie stanowi rezerwy mienia Skarbu Państwa na cele reprywatyzacji;

c) spółki zależne nie posiadają udziałów w kapitale zakładowym innych spółek tworzących tę grupę;

d) w spółkach tych nie występują zaległości we wpłatach podatków stanowiących dochód budżetu państwa.

Jeżeli spółki spełniają te warunki zawierają umowę o utworzeniu PGK w formie aktu notarialnego na okres co najmniej 3 lat podatkowych, która podlega rejestracji przez naczelnika urzędu skarbowego (ustawa o CIT, art. la ust. 2 pkt 2). Po zawiązaniu podatkowej grupy kapitałowej spółki dodatkowo muszą spełniać następujące warunki (ustawa o CIT, art. 1a ust. 1 pkt 3,4$)$ :

- nie mogą korzystać ze zwolnień od podatku dochodowego na podstawie odrębnych ustaw,

- nie mogą stosować cen odbiegających od cen rynkowych w stosunku do podmiotów, które nie wchodzą w skład podatkowej grupy kapitałowej,

- $\quad$ za każdy rok podatkowy muszą osiągnąć wymaganą wielkość (3\%) tzw. wskaźnika dochodowości (udział dochodu PGK w przychodach).

Niewątpliwie wymóg wykazywania określonej rentowności podatkowej przez podatkową grupę kapitałową stanowi istotny czynnik zniechęcający grupy kapitałowe do działania w tej formie podatkowej. Oznacza to bowiem, że podatkowa grupa kapitałowa jako całość nie może ponieść straty (Szlęzak-Matusewicz, 2008a, s. 146), a jeśli ją poniesie - strata ta nie podlega rozliczeniu z dochodami poszczególnych spółek (ustawa o CIT, art. 7a ust. 2). Ustawodawca zastrzegł również, że z dochodu podatkowej grupy kapitałowej nie pokrywa się strat spółek wchodzących w skład grupy, poniesionych przez nie w okresie przed powstaniem grupy (ustawa o CIT, art. 7a ust. 3) ${ }^{2}$.

Mimo powszechnie panującej opinii o restrykcyjnych warunkach zawiązania i funkcjonowania podatkowej grupy kapitałowej, z roku na rok obserwuje się wzrost liczby podatkowych grup kapitałowych (por. rys. 1 i 2). Słusznym wydaje się więc pogląd, że podatnicy coraz częściej i aktywniej optymalizują swoje obciążenia podatkowe. Niestety konstrukcja ta nie jest pozbawiona ryzyka podatkowego.

2 W świetle wydawanych interpretacji indywidulanych straty powstałe $\mathrm{w}$ spółkach przed zawiązaniem podatkowej grupy kapitałowej mogą być rozliczone po wygaśnięciu umowy o PGK. Okres funkcjonowania w podatkowej grupie kapitałowej nie jest wliczany do 5-letniego terminu rozliczania strat, por. szerzej np.: Interpretacja indywidulana z 24 maja 2013 r., ILPB3/423-89/13-2/AO. 


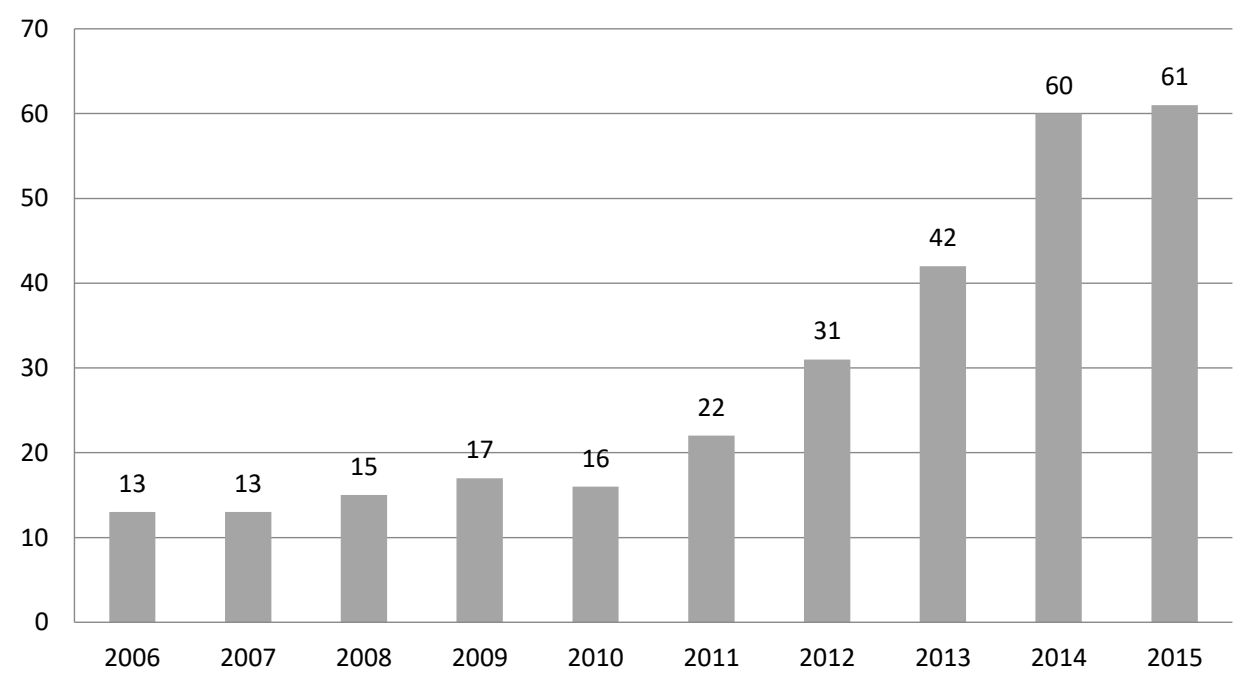

Rysunek 1. Liczba podatkowych grup kapitałowych w latach 2006-2015

Źródło: opracowanie własne na podstawie danych Ministerstwa Finansów: Informacja dotycząca rozliczenia podatku dochodowego od osób prawnych za lata 2006-2015.

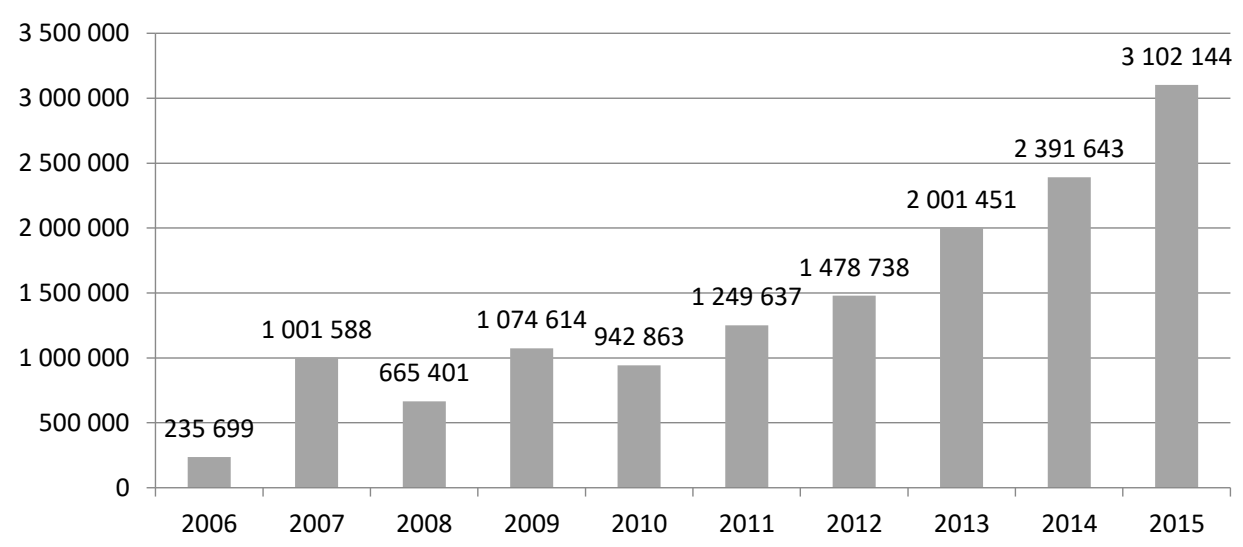

Rysunek 2. Kwota podatku dochodowego płaconego przez podatkowe grupy kapitałowe w latach 2006-2015 (w tys. zł)

Źródło: opracowanie własne na podstawie danych Ministerstwa Finansów: Informacja dotycząca rozliczenia podatku dochodowego od osób prawnych za lata 2006-2015. 


\section{Podatkowa grupa kapitałowa na gruncie podatku od towarów i usług}

Podatkowa grupa kapitałowa istnieje wyłącznie na gruncie podatku dochodowego w podatku od towarów i usług nie ma podmiotowości podatkowej. Podatnikami są więc spółki tworzące grupę kapitałową. Pojawia się więc pytanie czy taki dualizm w traktowaniu grupy kapitałowej może być źródłem ryzyka podatkowego (Szlęzak-Matusewicz 2008b, s. 48). Pytanie to dotyczy w głównej mierze tego co jest przedmiotem zainteresowania podatku dochodowego i podatku od towarów i usług - a więc ceny. Z punktu widzenia podatku dochodowego, spółki podatkowej grupy kapitałowej mogą dowolnie kształtować ceny wzajemnych transakcji a organ podatkowy nie ma podstaw do badania tych cen. Czy taka dowolność występuje także w podatku od towarów i usług? Jej zakres reguluje art. 32 ustawy o VAT, zgodnie z nim, gdy między nabywcą a dokonującym dostawy towarów lub usługodawcą istnieje powiązanie o charakterze rodzinnym, kapitałowym, majątkowym lub wynikającym ze stosunku pracy, oraz w przypadku gdy:

a) wynagrodzenie jest niższe od wartości wolnorynkowej, a odbiorca dostawy nie ma pełnego prawa do odliczenia;

b) wynagrodzenie jest niższe od wartości wolnorynkowej i dostawca ma częściowe prawo do odliczenia podatku, a sama czynność podlega zwolnieniu;

c) wynagrodzenie jest wyższe od wartości wolnorynkowej, a dostawca nie ma pełnego prawa do odliczenia.

Organ podatkowy określa podstawę opodatkowania zgodnie z wartością rynkową, jeżeli okaże się, że związek ten miał wpływ na ustalenie wynagrodzenia z tytułu dostawy towarów lub świadczenia usług; szacowanie podstawy opodatkowania przez organ podatkowy może więc wystąpić, gdy łącznie spełnione są następujące przesłanki:

- istnieje związek między kontrahentami,

- cena ustalona przez kontrahentów odbiega od ceny rynkowej,

- występują ograniczenia w prawie do odliczenia podatku naliczonego po stronie nabywcy lub dostawcy,

- wykazanie, że przyczyną ustalenia ceny nierynkowej były powiązania między kontrahentami.

Jeśli zatem jeden z opisanych warunków nie zostanie spełniony, organ podatkowy nie będzie miał podstaw do szacowania ceny. Ma to szczególne znaczenie w obrotach między podatnikami VAT czynnymi, w stosunku do których nie występują ograniczenia w odliczeniach podatku naliczonego. W tym bowiem przypadku art. 32 nie znajdzie zastosowania. W praktyce oznacza to, że spółki podatkowej grupy kapitałowej będą mogły swobodnie kształtować ceny bez ryzyka szacowania podstawy opodatkowania z punktu widzenia podatku od towarów i usług.

Znacznie trudniejsza jest sytuacja tych podatników, którzy w części lub w całości świadczą usługi zwolnione z VAT, ponieważ art. 32 ustawy o VAT może dotyczyć właśnie tych podatników. Kwestia zastosowania art. 32 była przedmiotem wielu interpretacji i orzeczeń sądów administracyjnych. 
W początkowym okresie funkcjonowania podatkowych grup kapitałowych organy podatkowe zgadzały się ze stanowiskiem podatkowych grup kapitałowych stosując wykładnię systemową do analizy przepisów. Argumentacja ta zakładała, że niedopuszczalne jest, aby zastosowanie konstrukcji dozwolonych i określonych w ramach jednego podatku (CIT) mogło prowadzić do negatywnych konsekwencji, a wręcz nakładania sankcji na podatnika na podstawie przepisów będących elementem konstrukcji podatku innego typu. Bazując na systemowej wykładni przepisów art. 32 ustawy o VAT oraz art. 11 ustawy o CIT, w kontekście podatkowej grupy kapitałowej, do szacowania obrotu w podatku VAT dla transakcji pomiędzy spółkami tej samej PGK nie powinno dochodzić, ponieważ w rzeczywistości prowadziłoby do odebrania podatnikowi możliwości stosowania w rozliczeniach wewnątrzgrupowych cen odbiegających od cen rynkowych, co jednocześnie zostało im zagwarantowane w przepisie art. 11 ust. 8 ustawy CIT i stanowi podstawowy element konstrukcji PGK. Jeśli by bowiem przyjąć, że art. 32 ustawy o VAT powinien mieć zastosowanie w podatkowych grupach kapitałowych, doprowadziłaby to do sytuacji, w której zastosowanie konstrukcji przewidzianej w ramach regulacji jednego podatku (CIT) ma negatywne konsekwencje w innym podatku $(\mathrm{VAT})^{3}$.

W podobnym tonie wypowiadały się również sądy administracyjne, w tym Naczelny Sąd Administracyjny (NSA, 2010; 2011). NSA wskazywał, że do szacowania podstawy opodatkowania może dochodzić, gdy spełnione są łącznie, określone w art. 80 ust. 1 Dyrektywy 2006/112, przesłanki oraz przede wszystkim cel regulacji, jakim jest uchylanie się od opodatkowania lub unikanie opodatkowania. Powstaje więc zasadnicze pytanie - czy stosowanie cen odbiegających od cen rynkowych w PGK może zostać uznane za działanie mające na celu uchylanie się od opodatkowania lub unikanie opodatkowania. Zdaniem NSA odpowiedź na to pytanie jest przecząca. NSA zwrócił także uwagę na kolizję przepisów art. 32 ustawy o VAT i uprawnień, jakie dają przepisy o podatkowej grupie kapitałowej w podatku dochodowym. Stosując wykładnię systemową uznał, że art. 32 ustawy o VAT nie powinien mieć więc zastosowania w podatkowych grupach kapitałowych.

Odwrócenie linii orzeczniczej nastąpiło już w 2012 roku. Naczelny Sąd Administracyjny w wyroku z 18 września 2012 roku (NSA, 2012) uznał, że jeżeli spełnione są przesłanki art. 32 ustawy o VAT, organ podatkowy ma prawo oszacować podstawę opodatkowania w podatkowej grupie kapitałowej. W kolejnych wyrokach NSA stwierdzał, że unormowanie dotyczące PGK na gruncie podatku dochodowego od osób prawnych, nie ma żadnego przełożenia na podatek VAT. Przepisy ustawy o podatku od towarów i usług nie przewidują tworzenia PGK, jak również tego, aby PGK utworzone na podstawie przepisów ustawy o podatku dochodowym od osób prawnych były podatnikami VAT. Tym samym są nimi wyłącznie spółki należące do PGK (NSA, 2012; 2013; 2014; 2015). Możliwości zastosowania art. 32 ustawy o VAT do transakcji dokonywanych między członkami PGK nie wyłączają też przepisy ustawy o podatku dochodowym od osób prawnych, w szczególności art. 11 ust.

3 Interpretacja indywidulana, lipiec 2006 - została wydana w stanie prawnym, gdy art. 32 ustawy o VAT miał inne niż dzisiejsze brzmienie. 
8 tej ustawy. Przepis ten wyłącza możliwość szacowania dochodu w przypadku świadczeń między spółkami tworzącymi PGK na gruncie podatku dochodowego od osób prawnych i w żadnym razie nie rozciąga się na stosunki podatkowe w podatku VAT.

Zmiana linii orzeczniczej rodzi ryzyko podatkowe związane z szacowaniem podstawy opodatkowania w tych podatkowych grupach kapitałowych, w których spółki mają ograniczone prawo do odliczenia podatku naliczonego. Szczególnie narażone będą więc te grupy, w skład których wchodzą banki, instytucje ubezpieczeniowe lub finansowe, przedsiębiorstwa świadczące usługi medyczne. W praktyce oznacza to, że te podatkowe grupy kapitałowe nie mogą w pełni korzystać z udogodnień jakie gwarantują im przepisy ustawy o podatku dochodowym od osób prawnych.

Zminimalizowaniu ryzyka szacowania podstawy opodatkowania służyć może zawarcie uprzedniego porozumienia cenowego. Systemowym rozwiązaniem problemu byłaby również zmiana ustawy o VAT i umożliwienie tworzenia grup vatowskich.

\section{Uprzednie porozumienia cenowe}

W świetle ustawy o VAT artykuł 32 nie ma zastosowania w przypadku transakcji zawieranych pomiędzy podmiotami powiązanymi, w odniesieniu do których organ podatkowy wydał decyzję o uznaniu prawidłowości wyboru i stosowania metody ustalania ceny transakcyjnej między podmiotami powiązanymi (ustawa o VAT, art. 32 ust. 5).

Uprzednie porozumienia cenowe (advance pricing arrangement - APA) funkcjonują w Polsce od 2006 roku. Regulacje z tego zakresu zostały zawarte w Ordynacji Podatkowej (Ordynacja Podatkowa, art. 20a-20r). Podpisanie takiego porozumienia eliminuje ryzyko zakwestionowania przyjętego poziomu cen przez organy podatkowe, ponieważ warunki cenowe transakcji między podmiotami powiązanymi są z wyprzedzeniem zaakceptowane przez organ podatkowy. Istota porozumień cenowych polega więc na określeniu - przed dokonaniem transakcji kontrolowanych - odpowiedniego zestawu kryteriów (np. metody, obiektów porównań i odpowiednich poprawek do nich, kluczowych założeń co do przyszłych zdarzeń) dla dokonywania wyceny transferu dla tych transakcji w ustalonym okresie. Chodzi tu o umowę zawieraną, co do zasady, na przyszłość pomiędzy podatnikiem a administracją podatkową, w której ten pierwszy zobowiązuje się stosować przyjętą metodę do objętych porozumieniem transakcji, w zamian uzyskując gwarancję, że stosowane przez niego ceny transakcyjne nie będą kwestionowane przez organy podatkowe. Nie można wobec niego oszacować obrotów, przychodów, kosztów z transakcji zawartych z danym kontrahentem.

Niestety uprzednie porozumienia cenowe są relatywnie drogim instrumentem ograniczającym ryzyko podatkowe. W przypadku porozumień jednostronnych (ograniczających ryzyko w odniesieniu do transakcji między podmiotami krajowymi) opłata wynosi od 5 do 50 tys. zł w przypadku podmiotów krajowych i od 20 do 100 tys. zł w przypadku podmiotów zagranicznych. Zawarcie porozumienia dwustronnego lub wielostronnego wymaga poniesienia kosztu od 50 do 200 tys. zł. 
Mimo licznych korzyści wynikających z zawarcia porozumienia, APA jest ciągle rzadko stosowanym narzędziem obrony warunków transakcyjnych w transakcjach wewnątrzgrupowych. Ze statystyk Ministerstwa Finansów wynika, że w ostatnich 10 latach podpisano jedynie 44 porozumienia (por. tab. 2). 20 wniosków o zawarcie porozumienia jest w trakcie rozpatrywania. Co więcej, stroną żadnego z tych porozumień nie jest spółka podatkowej grupy kapitałowej.

\section{Tabela 2}

Liczba porozumień cenowych w latach 2006-2017

\begin{tabular}{llll}
\hline APA & Jednostronne & Dwustronne & Wielostronne \\
\hline Zawarte & 39 & 4 & 1 \\
\hline W toku & 6 & 13 & 1 \\
\hline
\end{tabular}

Źródło: opracowanie własne na podstawie: http://www.finanse.mf.gov.pl/web/wp/cit/ceny-transferowe1/ uprzednie-porozumienia-cenowe-apa/statystyki-apa.

\section{Grupa vatowska (vat grouping)}

Grupa vatowska (vat grouping) to grupa przedsiębiorstw zarejestrowana dla celów VAT jako jeden podmiot. Funkcjonowanie tej instytucji przewiduje art. 11 Dyrektywy 2006/112/WE. Zgodnie z nim państwo członkowskie może traktować jako jednego podatnika VAT niezależne pod względem prawnym podmioty, które mają siedzibę na terytorium tego samego państwa członkowskiego oraz są ze sobą ściśle powiązane pod względem finansowym, ekonomicznym i organizacyjnym. Ponadto, państwa członkowskie mogą przyjąć wszelkie niezbędne środki, które uznają za koniczne, w celu zapobieżenia unikania opodatkowania lub uchylania się od niego na podstawie stworzonej w ten sposób możliwość grupowej rejestracji (Martini, 2011, s. 111). Vat grouping jest opcją, z której państwa członkowskie mogą skorzystać, ale nie muszą. Polska jak dotąd nie wprowadziła tego rozwiązania ze względu na potencjalny spadek dochodów budżetowych (Interpelacja, 2006).

Vat grouping funkcjonuje w Austrii, Belgii, na Cyprze, w Czechach, Dani, Estonii, Finlandii, Niemczech, na Węgrzech, w Irlandii, Holandii, Rumunii, Słowacji, Hiszpanii, Szwecji, Wielkiej Brytanii, we Włoszech i na Łotwie (Massin, Vyncke, 2009, s. 454).

Istota funkcjonowania grupy VAT polega na nieopodatkowaniu transakcji wewnątrz tej samej grupy podatkowej. Opodatkowane są jedynie te transakcje, których stroną są podmioty spoza grupy VAT. W praktyce pozwala to na (Lewandowski, Fałkowski, 2012, s. 75-76):

- uniknięcie kosztu w postaci nieodliczonego VAT w sytuacji, gdy odbiorcą jest podmiot niemający prawa lub z ograniczonym prawem do odliczenia VAT (np. instytucja finansowa),

- poprawę płynności w sytuacji, gdy część pomiotów wykazuje w deklaracji kwotę VAT do zapłaty, a inne mają nadwyżkę podatku naliczonego nad należnym. 
Wprowadzenie instytucji vat grouping w Polsce rozwiązałoby problem kolizji przepisów o podatkowej grupie kapitałowej i przepisów ustawy o podatku od towarów i usług w zakresie możliwości szacowania podstawy opodatkowania (ustawa o VAT, art. 32). Podatkowa grupa kapitałowa, która jednocześnie stałaby się podatnikiem VAT odniosłaby nie tylko opisane wcześniej korzyści, ale przede wszystkim wyeliminowałaby ryzyko podatkowe związane z szacowaniem podstawy opodatkowania.

\section{Uwagi końcowe}

Podatkowa grupa kapitałowa jest narzędziem optymalizacji podatkowej w podatku dochodowym, którego zastosowanie obniża obciążenia podatkowe. Nie ulega wątpliwości, że korzyści podatkowe, wynikające z funkcjonowania podatkowej grupy kapitałowej są zauważalne przez podatników, którzy coraz śmielej wykorzystują ten instrument w swojej polityce podatkowej. Fakt ten potwierdza wzrost liczby podatkowych grup kapitałowych w ostatnich latach. W 2006 roku było ich 13, a w 2015 roku - 61.

Regulacje dotyczące opodatkowania grup kapitałowych nie mają jednak charakteru kompleksowego. Wręcz przeciwnie, są one wewnętrznie niespójne a przepis jednej ustawy wyklucza zastosowanie regulacji dotyczącej innego podatku. To z kolei jest źródłem ryzyka podatkowego, którego zminimalizowaniu służyć może tylko jeden instrument - uprzednie porozumienia cenowe - jego zastosowanie jest jednak kosztowne i czasochłonne.

Słuszne wydaje się więc rozwiązanie tego problemu przez ustawodawcę, który powinien tę wewnętrzną kolizję przepisów usunąć, wprowadzając możliwość łącznego opodatkowania grup kapitałowych na gruncie podatku od towarów i usług. Vat grouping funkcjonuje w większości państw członkowskich Unii Europejskiej. Wprowadzenie tego instrumentu jest tym bardziej zasadne, że w swoich porządkach prawnych mają go takie kraje jak Węgry, Słowacja czy Czechy.

\section{Literatura}

Dyrektywa 2006/112/WE z dnia 28 listopada 2006 r. w sprawie wspólnego systemu podatku od wartości dodanej

(Dz. Urz. L 347 z 11 grudnia 2006 r., s. 1).

Informacja dotycząca rozliczenia podatku dochodowego od osób prawnych za 2006. Informacja dotycząca rozliczenia podatku dochodowego od osób prawnych za 2007. Informacja dotycząca rozliczenia podatku dochodowego od osób prawnych za 2008. Informacja dotycząca rozliczenia podatku dochodowego od osób prawnych za 2009. Informacja dotycząca rozliczenia podatku dochodowego od osób prawnych za 2010. Informacja dotycząca rozliczenia podatku dochodowego od osób prawnych za 2011. Informacja dotycząca rozliczenia podatku dochodowego od osób prawnych za 2012. Informacja dotycząca rozliczenia podatku dochodowego od osób prawnych za 2013. Informacja dotycząca rozliczenia podatku dochodowego od osób prawnych za 2014. Informacja dotycząca rozliczenia podatku dochodowego od osób prawnych za 2015. 
Interpretacja indywidulana z dnia 6 lipca 2006 r., 1471/NUR2/443-150/2/06/JP.

Interpretacja indywidualna z dnia 24 maja 2013 r., ILPB3/423-89/13-2/AO.

Kośmider, A. (2000). Podatkowe grupy kapitałowe. Zasady opodatkowania w 2000 r. i 2001 r. Doradca Podatnika, 12,7 .

Lewandowski, K., Fałkowski P. (2012). Dyrektywa VAT 2006/112. Komentarz. Warszawa: C.H. Beck.

Litwińczuk, H. (1995). Opodatkowanie koncernów, Przeglad Podatkowy, 2, 22.

Martini, J. (red.) (2011). Dyrektywa VAT 2006/112/WE. Komentarz. Wrocław: Unimex.

Massin, I., Vyncke, K. (2009). EC Communication on VAT Grouping: An Attempt to Harmonize or to Restrict the Use of Group Registration? International VAT Monitor, 11/12, 454-461.

Nowak, A. (red.) (2015). Podatkowa grupa kapitałowa. Warszawa: C.H. Beck.

Odpowiedź podsekretarza stanu w Ministerstwie Finansów z 27 kwietnia 2007 r. - z upoważnienia ministra - na interpelację $\mathrm{nr} 7598 \mathrm{w}$ sprawie tzw. grup VAT-owskich.

Szlęzak-Matusewicz, J. (2008b). Zarządzanie ryzykiem podatkowym w przedsiębiorstwie. Studia i Prace Kolegium Zarządzania i Finansów, 86, 48-58.

Szlęzak-Matusewicz, J. (2008a). Zarządzanie podatkami. Warszawa: Szkoła Główna Handlowa.

Ustawa z dnia 15 lutego 1992 r. o podatku dochodowym od osób prawnych (t.j. Dz.U. z 2016 r., poz. 1888 ze zm.).

Ustawa z dnia 29 sierpnia 1997 r. Ordynacja podatkowa (t.j. Dz.U. z 2015 r., poz. 613 ze zm.).

Ustawa z dnia 11 marca 2004 r. o podatku od towarów i usług (t.j. Dz.U. z 2016 r., poz. 710 ze zm.).

Wawrzyniak, B. (red.) (2002). Polskie grupy kapitatowe: perspektywa europejska. Warszawa: Wydawnictwo Wyższej Szkoły Przedsiębiorczości i Zarządzania im. L. Koźmińskiego.

Wyciślok, J. (2013). Optymalizacja podatkowa. Legalne zmniejszanie obciązeń podatkowych. Warszawa: C.H. Beck.

Wyrok NSA z dnia 26 maja 2010 r., sygn. akt I FSK 7891/02.

Wyrok NSA z dnia 28 listopada 2011 r., sygn. akt I FSK 155/11.

Wyrok NSA z dnia 28 września 2012 r., sygn. akt I FSK 617/12.

Wyrok NSA z dnia 18 września 2012 r., sygn. akt I FSK 617/12.

Wyrok NSA z dnia 8 marca 2013 r., sygn. akt I FSK 688/12.

Wyrok NSA z dnia 8 października 2013 r., sygn. akt I FSK 1536/12.

Wyrok NSA z dnia 4 września 2014 r., sygn. akt I FSK 1351/13.

Wyrok NSA z dnia 30 października 2014 r., sygn. akt I FSK 1579/13.

Wyrok NSA z dnia 4 grudnia 2014 r., sygn. akt I FSK 1778/13.

Wyrok NSA z dnia 16 maja 2015 r., sygn. akt I FSK 1579/13. 


\title{
TAX CAPITAL GROUP ON THE BASIS OF GOODS AND SERVICES TAX - THE RISK OF ESTIMATING THE TAX BASE
}

\begin{abstract}
Purpose - The tax capital group is a form of joint taxation of the capital group. Its application brings a number of tax advantages, including possibility of using transfer prices in internal transactions of the tax capital group. Under the VAT Act, tax capital group is not a taxpayer. Companies that form a tax group are taxpayers. This in turn means that prices in internal transactions must be on the market level. Thus, internal incohesion of the taxation rules is revealed. The provision of the VAT Act excludes the application of the provisions of the CIT Act. This in turn raises the tax risk. The purpose of the considerations in this article is to identify the source of the tax risk resulting from tax incohesion and to try to answer the question of how this risk can be minimized. Design/Methodology/approach - In the analysis, the author refers to tax regulations, tax individual interpretations and administrative court cases.

Findings - The author indicates that this risk can be minimized by applying advance pricing arrangements or amending the VAT Act by introducing a vat grouping instrument.

Originality/value - The value of the article is a cross-section analysis of the provisions of the tax capital group - not only in terms of income tax but also from the point of view of VAT regulations.
\end{abstract}

Keywords: tax capital group, tax risk, advance pricing arrangement, vat grouping, estimating, tax base

\section{Cytowanie}

Szlęzak-Matusewicz, J. (2017). Podatkowa grupa kapitałowa na gruncie podatku od towarów i usług - ryzyko szacowania podstawy opodatkowania. Finanse, Rynki Finansowe, Ubezpieczenia, 3 (87/2), 53-65. DOI: 10.18276/ frfu.2017.87/2-05. 